\title{
Marta Czekaj
}

\section{Plan sukcesji w gospodarstwie rolnym}

Streszczenie: Zagadnienia sukcesji są szeroko opisywane w odniesieniu do firm rodzinnych, w których większość następców to osoby pochodzące z kręgu najbliższej rodziny. Sukcesja jest równie ważna w przypadku gospodarstw rolnych. Ciągłość przekazywania tych podmiotów kolejnym członkom rodziny rolnika wpływa na osiągnięcie sukcesu przez nowego właściciela, który powinien być do tej roli właściwie przygotowany. Przygotowanie takie może być zapewnione poprzez opracowanie i wdrożenie planu sukcesji gospodarstwa rolnego. W artykule dokonano analizy planów sukcesji przygotowanych dla potrzeb podmiotów rodzinnych. Ponadto zostały prześledzone rozwiązania stosowane w odniesieniu do planowania sukcesji w gospodarstwach rolnych poza granicami Polski. Na bazie zebranych informacji stworzono schemat planu sukcesji w gospodarstwie rolnym. Planowanie sukcesji powinno być upowszechniane wśród rolników w Polsce. Plan taki pobudza do rozważań dotyczących przyszłości gospodarstwa rolnego. W polskim rolnictwie planowanie sukcesji to zagadnienie wciąż jeszcze mało bądź nawet w ogóle nieznane, a badania $\mathrm{z}$ tego zakresu w Polsce nie były dotąd prowadzone.

Słowa kluczowe: planowanie, sukcesja, firma rodzinna, gospodarstwo rodzinne.

\section{Wstęp}

Dziedziczenie efektów pracy w podmiotach familijnych jest przedmiotem zainteresowania wszystkich członków rodziny, a sama sukcesja dokonana w ramach spokrewnionej grupy osób jest także wyznacznikiem kwalifikującym dany podmiot do grupy przedsiębiorstw rodzinnych (Kałuża 2009). Przejęcie rodzinnego biznesu może być różnie postrzegane przez sukcesorów - dla jednych będzie to szczyt marzeń, cel, któremu podporządkowali dotychczasowe życie, począwszy od sposobu spędzania wolnego czasu (pomoc najbliższym, a w szczególności rodzicom w wypełnianiu ich obowiązków), przez obranie kierunku i stopnia edukacji (wykształcenie zawodowe, średnie czy wyższe, ogólne czy kierunkowe), a na życiu osobistym

Dr inż. Marta Czekaj, Uniwersytet Rolniczy im. Hugona Kołłątaja w Krakowie, Wydział Rolniczo-Ekonomiczny, Instytut Ekonomiki i Zarządzania Przedsiębiorstwami, Zakład Zarządzania i Marketingu, martaczekaj@poczta.onet.pl. 
skończywszy (dobór partnera/partnerki życiowej, która to osoba będzie wspierać sukcesora w prowadzeniu przejętej działalności). Dla innych następców może to z kolei oznaczać konieczność spełnienia przykrego obowiązku uniemożliwiającego realizację własnych planów i zamierzeń na przyszłość. Sukcesja to także odrębne zagadnienie dla seniorów, którzy z jednej strony przygotowują swoich następców, $\mathrm{z}$ drugiej nie bez obaw oddają $\mathrm{w}$ ich ręce dorobek życia swojego, a nierzadko i poprzednich pokoleń. Zgodnie z raportem Firmy rodzinne w polskiej gospodarce: Szanse i wyzwania (Kowalewska 2009) wśród działających w Polsce firm rodzinnych dominują te prowadzone przez pokolenie założycieli, 15\% prowadzonych jest przez drugie, a co setna przez trzecie pokolenie. Z kolei w USA tylko 30\% podmiotów rodzinnych „przeżywa” przekazanie pomiędzy pierwszym i drugim pokoleniem, $14 \%$ między drugim a trzecim, mniej niż $5 \%$ pomiędzy trzecim a czwartym (Horak, Surdej 2015).

Podobne dylematy rozstrzygane są $\mathrm{w}$ temacie dziedziczenia gospodarstw rolnych, których prowadzenie nie zawsze jest priorytetem dla członków rodziny rolnika. Pasja i zapał rodziców, którzy niejednokrotnie dysponują przekazywanym od pokoleń majątkiem produkcyjnym, w tym zasobami ziemi (z tym czynnikiem część rolników związana jest emocjonalnie) nie zawsze jest podzielana przez potomków. Tymczasem przetrwanie wielu działających w Polsce gospodarstw rodzinnych jest uzależnione od właściwie przeprowadzonego międzypokoleniowego procesu sukcesji oraz utrzymania prowadzonej działalności rolniczej przez sukcesora. Większość młodych rolników w Polsce to osoby, które użytkowane gospodarstwo nabyły w drodze dziedziczenia ojcowizny (Musialska 2015), nieliczne są przypadki nabywania ziemi przez ludzi młodych celem prowadzenia działalności rolniczej. Ciągłość przekazywania gospodarstwa rolnego członkom rodziny wpływa także na osiągnięcie sukcesu przez kolejnego właściciela - wychowany w rodzinie rolniczej następca zwykle dysponuje wiedzą i umiejętnościami, których często nie mają osoby legitymujące się np. wyższym wykształceniem rolniczym. Rodzice-rolnicy budują w dzieciach (potencjalnych następcach) przywiązanie do ziemi i ojcowizny, zachęcają do pomocy i współpracy w ramach prostych prac gospodarskich, a przygotowanie progenitury do przejęcia roli pełnionej przez właścicieli gospodarstwa budzi tyleż nadziei i radości, co niepokoju i obaw. Ta swoista sztafeta pokoleń osiągnie swój cel, jeżeli właściwie dobierze kolejnych „zawodników” przejmujących pałeczkę.

Dominująca część działających w Polsce gospodarstw rolnych to gospodarstwa rodzinne - stanowią one 99\% ogółu (www.farmer.pl), a kontrowersje wzbudza rozróżnienie terminów: gospodarstwa rolnego i przedsiębiorstwa rolnego (rolnika i przedsiębiorcy). Można wymienić szereg podobieństw pomiędzy tymi dwoma jednostkami (Pijanowska 2016), jednak dość dużo autorów definiuje osobno te dwa pojęcia, wskazując, że przedsiębiorstwo rolne to jednostka ekonomiczna 
produkująca dobra przeznaczone na rynek, natomiast gospodarstwo rolne to jednostka techniczno-produkcyjna, wyodrębniona organizacyjnie, dysponująca zasobami ziemi, pracy i kapitału, które są wykorzystywane do produkcji rolniczej (Budzinowski, Suchoń 2015; Ziętara 2009). W opracowaniu przyjęto, że gospodarstwo rolne to gospodarstwo rodzinne spełniające wymogi opisane w Ustawie z dnia 11 kwietnia 2003 r. o kształtowaniu ustroju rolnego, czyli o powierzchni do 300 ha, prowadzone przez indywidualnego rolnika.

Porównując procesy sukcesji w przedsiębiorstwach i gospodarstwach rodzinnych, warto zastanowić się nad stopniem podobieństwa tych podmiotów. Rodzinne gospodarstwa rolne i firmy rodzinne cechują się podobieństwem $\mathrm{z}$ racji tego, że w obu przypadkach mamy do czynienia z działalnością prowadzoną wspólnie przez członków rodziny. Czy jednak rodzinne gospodarstwo rolne może być uznane za firmę rodzinną? Polska Agencja Rozwoju Przedsiębiorczości (PARP) wskazuje następującą definicję firmy rodzinnej:

firma rodzinna to każdy podmiot gospodarczy z sektora mikro, małych lub średnich przedsiębiorstw, o dowolnej formie prawnej, zarejestrowany i działający w Polsce, w którym: wspólnie pracuje co najmniej dwóch członków rodziny, co najmniej jeden członek rodziny ma istotny wpływ na zarządzanie przedsiębiorstwem, członkowie rodziny posiadają znaczące udziały w przedsiębiorstwie (Kowalewska 2009),

wyliczając jednocześnie tzw. kryteria wyłączające, eliminujące dany podmiot z grupy firm rodzinnych, np. podmioty działające w takich branżach jak rolnictwo, łowiectwo, leśnictwo, rybactwo, administracja publiczna, gospodarstwa domowe zatrudniające pracowników, organizacje i zespoły eksterytorialne (Kowalewska 2009). W świetle prezentowanych ograniczeń gospodarstwa rolne są wykluczone z grupy firm rodzinnych. Z kolei Kazimierz Orzechowski (2011) wskazuje, że „przedsiębiorstwo rodzinne można zdefiniować jako takie, którego podstawowe zasoby ludzkie stanowi rodzina kształtująca bezpośrednio jego działalność", podobnie uważa Łukasz Sułkowski (2011). Jedna z definicji firmy rodzinnej podkreśla, że jest to taki podmiot, $w$ którym proces sukcesji prowadzony jest $w$ ramach rodziny właścicieli, jej członkowie biorą aktywny udział w prowadzeniu jednostki gospodarczej oraz pracują w tej w firmie (Kałuża 2009). W świetle ostatniej definicji można uznać, że gospodarstwa rolne będą się kwalifikowały do grupy przedsiębiorstw rodzinnych, o ile prowadzone będą przez producenta rolnego, którego rodzina współpracuje z nim w ramach tego gospodarstwa. Wybrani ekonomiści rolni wprost wskazują, że gospodarstwo rodzinne należy zaliczyć do grupy firm rodzinnych (Klank 2006), można zatem przyjąć, że rozwiązania przyjęte w zakresie sukcesji 
w firmach rodzinnych można - przynajmniej w części - spróbować przenieść na grunt podobnych rozważań dotyczących sytuacji gospodarstw rolnych.

\section{Uwagi metodyczne}

Prezentowane opracowanie porusza zagadnienie planowania sukcesji w szeroko pojętych podmiotach rodzinnych. Głównym celem artykułu jest próba wskazania teoretycznych etapów planu sukcesji w gospodarstwach rodzinnych, a także zwrócenie uwagi na brak takich rozwiązań w gospodarstwach rolnych w Polsce. Przegląd literatury wskazuje, że zagadnienie to nie było dotychczas poruszane $\mathrm{w}$ odniesieniu do funkcjonujących w Polsce gospodarstw rolnych, $\mathrm{z}$ kolei doświadczenia producentów rolnych $\mathrm{z}$ wybranych krajów Europy i świata dają podstawy do stwierdzenia, że jest to ważna kwestia. Planowanie procesu sukcesji zwiększa prawdopodobieństwo przetrwania gospodarstwa rolnego i dostarcza informacji o jego stanie obecnym oraz o przyszłości. Brak planów sukcesyjnych w gospodarstwach rolnych w Polsce może wpisywać się w przyczyny problemów ekonomii obszarów wiejskich.

Punkt wyjścia do stworzenia planu stanowily dostępne w literaturze przedmiotu plany następstwa w firmach rodzinnych w Polsce i na świecie oraz doświadczenia gospodarstw rolnych $\mathrm{z}$ wybranych krajów rozwiniętych $\mathrm{w}$ planowaniu sukcesji. Bazując na tych informacjach, podjęto próbę skonstruowania planu sukcesji gospodarstwa rolnego $\mathrm{w}$ formie schematu obrazującego kolejne etapy tego procesu. Do realizacji celów wskazanych w opracowaniu wykorzystano metodę opisową, metodę graficzną oraz metodę komparatystyczną.

\section{Znaczenie planu sukcesji na przykładzie firm rodzinnych}

Wśród polskich przedsiębiorstw rodzinnych dominują podmioty małe i średnie. Szacunki podają, że w Polsce w 2012 r. działało około 1,8 mln firm, w tym około 80\% stanowily podmioty rodzinne (Piekarski, Rudzińska 2012). W ramach ogólnie wytyczonych kierunków wspierania rodzinnych firm podnosi się konieczność stworzenia strategii biznesu rodzinnego, a w jej ramach zbudowania planu sukcesji. Konstrukcja takiego planu powinna uwzględniać prawne aspekty sukcesji i być poprzedzona konsultacjami prowadzonymi w kręgu rodziny, ale także rozmowami z fachowcami i doradcami z zewnątrz (Więcek-Janka 2014). Niestety nie wszyscy zarządzający w firmach rodzinnych zgłaszają konieczność posiadania planu sukcesji. Badania prowadzone w 2013 r. wśród polskich firm rodzinnych wykazały, że $12,2 \%$ nestorów uważa, że nie ma potrzeby tworzenia takiego planu, takiej samej odpowiedzi udzieliło 13,2\% sukcesorów (Lewandowska 2013). Planowanie 
sukcesji jest także dość często pomijane w krajach, w których rozwój prywatnej przedsiębiorczości ma o wiele głębsze korzenie - np. w USA w 2014 r. 80\% firm familijnych planowało sukcesję $\mathrm{w}$ ramach rodziny, ale tylko $19 \%$ przygotowało pisemny projekt tego procesu (Horak, Surdej 2015).

Plan sukcesji powinien mieć wzgląd na przygotowanie sukcesora, kierownictwa oraz pracowników firmy na zmianę dotychczasowego właściciela. Planowanie sukcesji w firmach rodzinnych jest często prezentowane graficznie w postaci faz, zbioru następujących po sobie zachowań, mających pomóc właściwie ten proces przygotować. Adrianna Lewandowska z zespołem (2012) wyróżnia kilka elementów planowania sukcesji w rodzinnych firmach (rys. 1). Wskazuje, że podstawowym składnikiem $z$ sukcesem przeprowadzonego procesu przekazywania własności jest zaangażowanie członków rodziny, przy czym koncentruje się tu w szczególności na osobie nestora. Podkreśla fakt, że często to dotychczasowy właściciel wykazuje zbyt małe zainteresowanie procesem sukcesji, przyjmując za pewnik, że „obecność sukcesora to wszystko, co potrzeba, aby sukcesja była skuteczna” (Lewandowska, Greser, Jakubowski 2012).

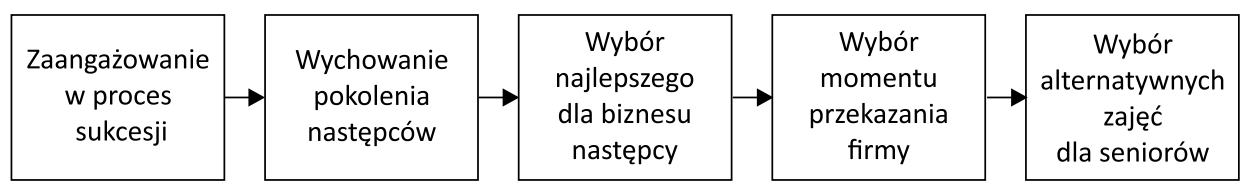

Rysunek 1. Elementy planu sukcesji w firmach rodzinnych

Figure 1. Elements of succession plan in family businesses

Źródło: Lewandowska, Greser, Jakubowski 2012.

Source: Lewandowska, Greser, Jakubowski 2012.

Jako kolejny element wskazywane jest wychowanie pokolenia następców - nie zawsze wiadomo, który spośród potomków właścicieli taką rolę w firmie przejmie. Co jednak ważne, aby przyszły kierownik dobrze zarządzał powierzoną mu własnością, konieczne jest wykształcenie w nim cech dobrego przywódcy i przedsiębiorcy. Cechy te może zdobyć, obserwując i zapamiętując poczynania dotychczasowych kierowników, tym bardziej że, jak wskazują antropolodzy, człowiek „,nie wyewoluował, żeby myśleć, lecz zapamiętywać i imitować” (Henneberg 2016). Spośród osób przygotowywanych do objęcia rodzinnego biznesu należy wyłonić jedną, najlepiej spełniającą kryteria wyznaczone przez sukcesora - następuje to w kolejnym etapie planu sukcesji. Jednym z trudniejszych elementów jest wyznaczenie momentu przekazania władzy kolejnemu pokoleniu. Zauważyć przy tym należy, że sukcesja jest postrzegana jako proces, a nie zdarzenie jednorazowe, stąd trudno nawet na 
etapie planowania wskazać konkretną datę, od której dotychczasowy właściciel nie będzie się angażował $\mathrm{w}$ procesy związane $\mathrm{z}$ firmą. Sukcesja bywa często rozłożona w czasie nawet na kilkanaście lat i wymaga w tym okresie ciągłej współpracy dotychczasowych właścicieli z osobami planowanymi do roli następcy. Badania prowadzone na temat sukcesji w firmach rodzinnych potwierdzają, że chociaż ich właściciele zdają sobie sprawę z własnych ograniczeń wynikających z wieku czy stanu zdrowia i w związku z tym z konieczności przekazania majątku następcy, to jednak ,ich podstawowym odruchem [...] jest odsuwanie w czasie nie tylko samego etapu przekazania, ale też wszelkich faz składających się na proces zmian generacyjnych i sukcesji” (Safin, Pluta 2014). Co więcej szacunki podają, że około $1 / 3$ właścicieli firm rodzinnych, decydując się przekazać władzę następcom, liczy już więcej niż 65 lat. Tymczasem wybrani autorzy wskazują, że proces sukcesji powinien przyjąć sformalizowaną postać spisanego planu najpóźniej 5 lat przed momentem przekazania majątku (może to być np. chwila osiągnięcia wieku emerytalnego), a jego przegląd i aktualizacja powinny być wykonywane przynajmniej raz na trzy lata (Wilkinson, Sykes 2007). Ostatnim etapem planowania sukcesji jest określenie aktywności podejmowanych przez seniorów po rozstaniu się z obowiązkami kierownika. W ramach tego wskazuje się np. możliwość włączenia go w sprawy firmowe przez zapewnienie mu funkcji doradcy-konsultanta.

Krzysztof Safin i Jacek Pluta (2014) w ramach modelu sukcesji w przedsiębiorstwach rodzinnych wskazują wyodrębnienie procesu sukcesji i wymieniają jego cztery elementy składowe, które również wymagają poczynienia odpowiednich planów: przygotowanie, wykształcenie następcy, wybór następcy oraz przekazanie kierownictwa (łącznie $\mathrm{z}$ transferem kapitału). W literaturze proces sukcesji bywa też znacznie bardziej szczegółowo przedstawiony i obejmuje fazy: przedbiznesową, wprowadzającą w biznes, wprowadzającą funkcjonalną, funkcjonalną, zaawansowaną funkcjonalną, wczesnej sukcesji i końcową - dojrzałej sukcesji (Kowalewska 2009). Z kolei Paweł Rataj (2012) podkreśla, że dobrze opracowany plan przekazania majątku rodzinnego powinien szczególnie mocno skupiać się na osobie przekazującej firmę i zadbać o jej zabezpieczenie finansowe. Podnosi on także kwestię uwzględnienia $\mathrm{w}$ tym planie takich aspektów, jak sprawiedliwe rozporządzenie przekazywanym majątkiem ( $w$ taki sposób, aby żaden z grupy sukcesorów nie poczuł się w jakiś sposób pominięty) oraz zatrzymanie w podmiocie najbardziej wartościowych pracowników (spoza grona rodzinnego), którzy w chwili zmiany właściciela firmy mogą chcieć $\mathrm{z}$ niej odejść. $\mathrm{W}$ przypadku firm rodzinnych kwestie planowania zmiany zarządzającego są silnie powiązane $\mathrm{z}$ różnego rodzaju obciążeniami podatkowymi (Rataj 2012). Zmiana własności może bowiem w przypadku przedsiębiorstw nieść na gruncie przepisów podatkowych zarówno pozytywne, jak i negatywne konsekwencje. Odpowiednie rozplanowanie tego procesu oznacza 
wykorzystanie szans i uniknięcie zagrożeń. W kwestii planowania sukcesji w firmach rodzinnych często pojawia się jeszcze inne spojrzenie na ten proces, skupiające się na zagadnieniach kapitałowych, gdyż szczególnie ostrożnie planuje się finansowe konsekwencje decyzji sukcesyjnych. Oprócz wspominanego już wcześniej zabezpieczenia finansowego seniorów opracowywane są koncepcje dotyczące różnorodnych rozliczeń (rys. 2). Mogą one być konieczne do przeprowadzenia w gronie rodzinnym, ale także między wspólnikami niepołączonymi więzami krwi. Współpraca między członkami rodziny może już nie układać się tak korzystnie w momencie, gdy zabraknie dotychczasowego kierownika. W takiej sytuacji, aby firma przetrwała, dobrze jest zaplanować, skąd pochodziły będą środki na spłatę rodziny i tak zaprojektować uiszczenie zobowiązań, aby zadowolić wszystkie strony. W ramach planów sukcesji ważne jest także zabezpieczenie spłaty długów spadkowych, a rozwiązaniem tu proponowanym - wykup ubezpieczenia na życie, z którego środki mogą w przyszłości rozwiązać omawiany problem. Wspólnicy spoza grona rodzinnego także mogą - w momencie zmiany kierownika - zażądać spłaty swoich wkładów, a taka sytuacja może doprowadzić nawet do zaburzeń wypłacalności podmiotu, gdy nowy właściciel nie będzie w stanie spłacić tych roszczeń. Należałoby jeszcze rozważyć sprawę obciążeń wynikających z faktu otrzymania darowizny lub spadku i także zaplanować - przynajmniej w zarysie - kwestie spłaty zobowiązań podatkowych z tego tytułu. W sytuacji firm rodzinnych brak planu sukcesji - szczególnie w przypadku śmierci dotychczasowego właściciela - może mieć poważne konsekwencje dla dalszego istnienia podmiotu rodzinnego. Nieuregulowane za życia nestora sprawy własności mogą prowadzić nawet do upadku firmy.

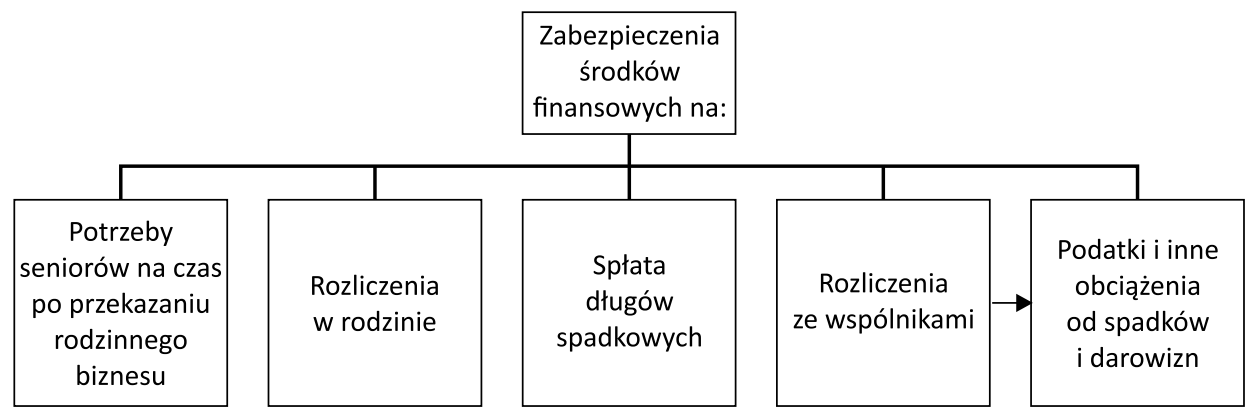

Rysunek 2. Finanse w planowaniu sukcesji w firmach rodzinnych

Figure 2. Financial aspects of succession plan in family businesses

Źródło: opracowanie własne na podstawieł. Martyniec, Finansowe aspekty planu sukcesji w firmach rodzinnych. 5 podstawowych potrzeb finansowych, które warto przewidzieć. Dostęp online: www.planowaniespadkowe.pl. Source: Own elaboration based on $Ł$. Martyniec, Finansowe aspekty planu sukcesji w firmach rodzinnych. 5 podstawowych potrzeb finansowych, które warto przewidzieć. Dostęp online: www.planowaniespadkowe.pl. 
Na proces formalnej sukcesji firmy rodzinnej wpływ ma również system wsparcia kierowany do następców (np. w gospodarstwach rolnych środki możliwe do pozyskania w ramach programu „Premie dla młodych rolników” [www.arimr. gov.pl]) czy konstrukcja systemu ubezpieczeń społecznych, co jest szczególnie widoczne w przypadku drobnych podmiotów rolniczych. Uzależnienie prawa do świadczeń emerytalnych od zaprzestania działalności rolniczej przez nestora, przy jednoczesnym braku realnych następców, którzy chcieliby ją kontynuować, sprzyja zjawisku „sukcesji pozornej”, która na ogół odsuwa tylko w czasie pełną likwidację danego gospodarstwa rolnego (Wojewodzic 2013; Satoła, Czekaj 2015).

Nie ulega wątpliwości, że planowanie sukcesji jest ważnym elementem ciągłości podmiotów rodzinnych. Uzupełniając to, co już zostało przedstawione w opracowaniu, należy wspomnieć także o emocjonalnych aspektach planowania sukcesji. Odpowiednio przygotowana sukcesja eliminuje konflikty w rodzinie, daje szanse podziału majątku pomiędzy wszystkich jej członków oraz - co jest nie do przecenienia - poczucie sprawiedliwego potraktowania. Zamykając tę część rozważań, warto nadmienić, że sprawiedliwy podział nie zawsze oznacza parcelowanie majątku w równych częściach dla każdego.

\section{Planowanie sukcesji w gospodarstwach rolnych na przykładzie wybranych krajów}

Planowanie sukcesji gospodarstw rolnych - podobnie jak w przypadku przedsiębiorstw - warunkuje sukces tych podmiotów (Spafford 2016). Jest niezbędne, aby gospodarstwo potrafiło w odpowiedni sposób zaadaptować się do zmieniających się warunków otoczenia, w którym funkcjonuje (Wheeler et al. 2012), kreuje jego trwałość i wytrzymałość (Inwood, Sharp 2012). Co więcej, konieczne jest tworzenie „pisemnych” wersji planów sukcesji (Lawton 2013) - już taki prosty zabieg ujawnia pierwsze problemy z przekazywaniem gospodarstw rolnych, gdy np. przewidywane na to stanowisko osoby nie chcą podejmować takich zobowiązań i pojawia się (niezauważany lub ignorowany wcześniej) problem braku następcy bądź też chęć przejęcia rodzinnego gospodarstwa zgłasza więcej niż jeden członek rodziny (Gudorf, Beckett 2009). Planowanie sukcesji może być także momentem krytycznym w gospodarstwie rolnym. Jak wskazuje Sarah Johnsen (2004, s. 425), „[...] odporność i przedsiębiorczość rolników prowadzących gospodarstwa rolne są najbardziej zauważalne w okresie restrukturyzacji, gdy zdolność gospodarstw rodzinnych do przetrwania zależy od gotowości jego kierownika do zmiany sposobu postępowania”.

Bazując na doświadczeniach wybranych krajów na temat planowania sukcesji $\mathrm{w}$ gospodarstwach rolnych, należy zauważyć, że proces ten jest rozpatrywany w trzech 
aspektach związanych z czynnikiem ludzkim: pracy, zarządzania (kierowania) oraz własności gospodarstwa. Wśród wymienionych to praca (siła robocza) jest zwykle pierwszym elementem wymiany międzygeneracyjnej. Następuje bezpośrednia zamiana - następcy coraz aktywniej włączają się w pracę w gospodarstwie i przejmują część obowiązków od rodziców. Przekazanie kontroli nad gospodarstwem to jeden z trudniejszych etapów sukcesji, który warunkuje jej sukces.

Wytyczne dotyczące przygotowanie pisemnej wersji planu sukcesji w gospodarstwach rolnych znaleźć można np. na stronie kanadyjskiego Ministerstwa Rolnictwa, Żywności i Spraw Wiejskich (www.omfara.gov.on.ca). Zgodnie z nimi przygotowanie takiego planu wymaga rozważenia pewnych zagadnień i postawienia sobie kilku pytań: czy celem rolnika jest przekazanie gospodarstwa rolnego następnemu pokoleniu? Jeżeli tak, to kim jest następca? Ważne jest to, aby sukcesor brał udział w sprawach dotyczących gospodarstwa, podejmował decyzje. Dalej należy się zastanowić, jakie są cele i zobowiązania gospodarstwa i następcy. Kolejne pytanie, na które trzeba odpowiedzieć, to czy gospodarstwo rolne jest dochodowe i to zarówno w krótszej, jak i w dłuższej perspektywie? Jeżeli nie, to jakie działania będą podejmowane w przyszłości, aby zmienić tę sytuację? Jaki jest przewidywany czas ich realizacji? Po rozpatrzeniu tych kwestii można przystąpić do spisania planu sukcesji. W Kanadzie plan taki powinien zawierać informacje dotyczące: sytuacji gospodarstwa, strategii działania na przyszłość, planów emerytalnych dotychczasowych właścicieli, planów zarządzania, kontroli i transferu czynnika pracy, planów przekazania prawa własności, planów finansowych oraz harmonogram działań. Ponadto załącznikami do planu mogą być wszelakie dokumenty wykorzystywane w gospodarstwie bądź w nim generowane.

Zalecenia dotyczące sposobu przygotowywania planu sukcesji w gospodarstwie rolnym można znaleźć także w publikacjach słoweńskich, gdzie wyróżnia się w nim podobne elementy, jak w planie sukcesji proponowanym do stworzenia przez kanadyjskich rolników. Ponadto uznaje się, że dobrze przygotowany plan przekazania gospodarstwa (Kerbler 2012):

- zapewnia wystarczająco dużo czasu, aby zabezpieczyć odpowiedni dochód dla nestorów,

- pozwala na osiągnięcie przez gospodarstwo rolne takiego poziomu rozwoju, który nie będzie wymagał natychmiastowej interwencji następców, a przez to będą oni mogli stopniowo wdrażać się w nową rolę, bez obawy o sytuację finansową swoją i najbliższych,

- prezentuje sytuację gospodarstwa rolnego w chwili jego sporządzenia w sposób realny, a zamierzenia na przyszłość są wykonalne,

- motywuje kolejne pokolenia do pracy w gospodarstwie i budowania jego przyszłości, 
- zachęca do kreowania i rozwijania wśród następców umiejętności związanych nie tylko z działalnością rolniczą.

Z kolei w Australii znaleźć można propozycje stworzenia listy zadań w ramach planu sukcesji (seccession planning checklist) dla gospodarstw rolnych $\mathrm{w}$ formie pytań oraz harmonogramu, w którym etapy planu sukcesji będą realizowane. Harmonogram ten jest ustalany przez sukcesora, a jego idea ma pomóc mu rozłożyć w czasie zagadnienia sukcesji. Poszczególne etapy to: zbieranie informacji, opracowanie opcji na przyszłość gospodarstwa rolnego, rozpoczęcie procesu podejmowania decyzji dotyczących sukcesji, ciągły rozwój i korygowanie planu sukcesji, wprowadzenie planu sukcesji w życie (Wilkinson, Sykes 2007).

W $2001 \mathrm{r}$. w USA przeprowadzono szerokie badania gospodarstw rolnych obejmujące m.in. tematykę planowania emerytur i sukcesji w gospodarstwach rolnych. Badania te miały zasięg krajowy, a uczestniczyły w nich jednostki sprzedające w ciągu roku produkcję rolną o wartości co najmniej 1000 USD (Mishra, Johnson, Morehart 2003). Wśród badanych tylko $27 \%$ osób wskazało, że posiada plan sukcesji gospodarstwa rolnego. Dokładniejsza analiza dowiodła, że plan sukcesji sformułowało 34\% rolników, którzy zamierzali przejść na emeryturę w ciągu najbliższych 5 lat, 36\% badanych, którzy planowali zaprzestać prowadzenia gospodarstwa rolnego na rzecz uruchomienia innej działalności, oraz $40 \%$ z grupy producentów w wieku 65 lat i więcej. Co więcej, im młodsi byli rolnicy, tym mniejszy był w danej grupie wiekowej odsetek osób, które przygotowały plan sukcesji.

Wzorów do tworzenia planów sukcesji można poszukiwać także wśród najbardziej rozwiniętych krajów UE - badania prowadzone w Niemczech oraz w Austrii potwierdzają konieczność konstruowania planu sukcesji, sformułowano tam nawet tezę, że jest on niezbędny dla dalszego rozwoju gospodarstw rodzinnych (Glauben, Tietje, Vogel 2004). Planowanie sukcesji pomaga w rozłożeniu w czasie czynności związanych z przekazaniem gospodarstwa, nie można jednak takiego planu traktować jako sztywnego szablonu wyznaczającego sposób postępowania. W toku prowadzonej działalności, pod wpływem informacji płynących z otoczenia, może wystąpić konieczność przeredagowania przyjętych założeń.

\section{Próba stworzenia planu sukcesji gospodarstw rolnych w Polsce}

Konstrukcja planu działań sukcesyjnych $\mathrm{w}$ gospodarstwie rolnym wymaga kompleksowego podejścia i uwzględnienia w nim wielu czynników o charakterze zewnętrznym i wewnętrznym. Bazując na tworzonych dla firm rodzinnych planach sukcesji, w opracowaniu podjęto próbę opracowania takiego narzędzia dla gospodarstw rolnych (rys. 3). Pewnych przesłanek do stworzenia planu dostarczyły także przykłady zaczerpnięte z literatury przedmiotu (Succession... (c)), 


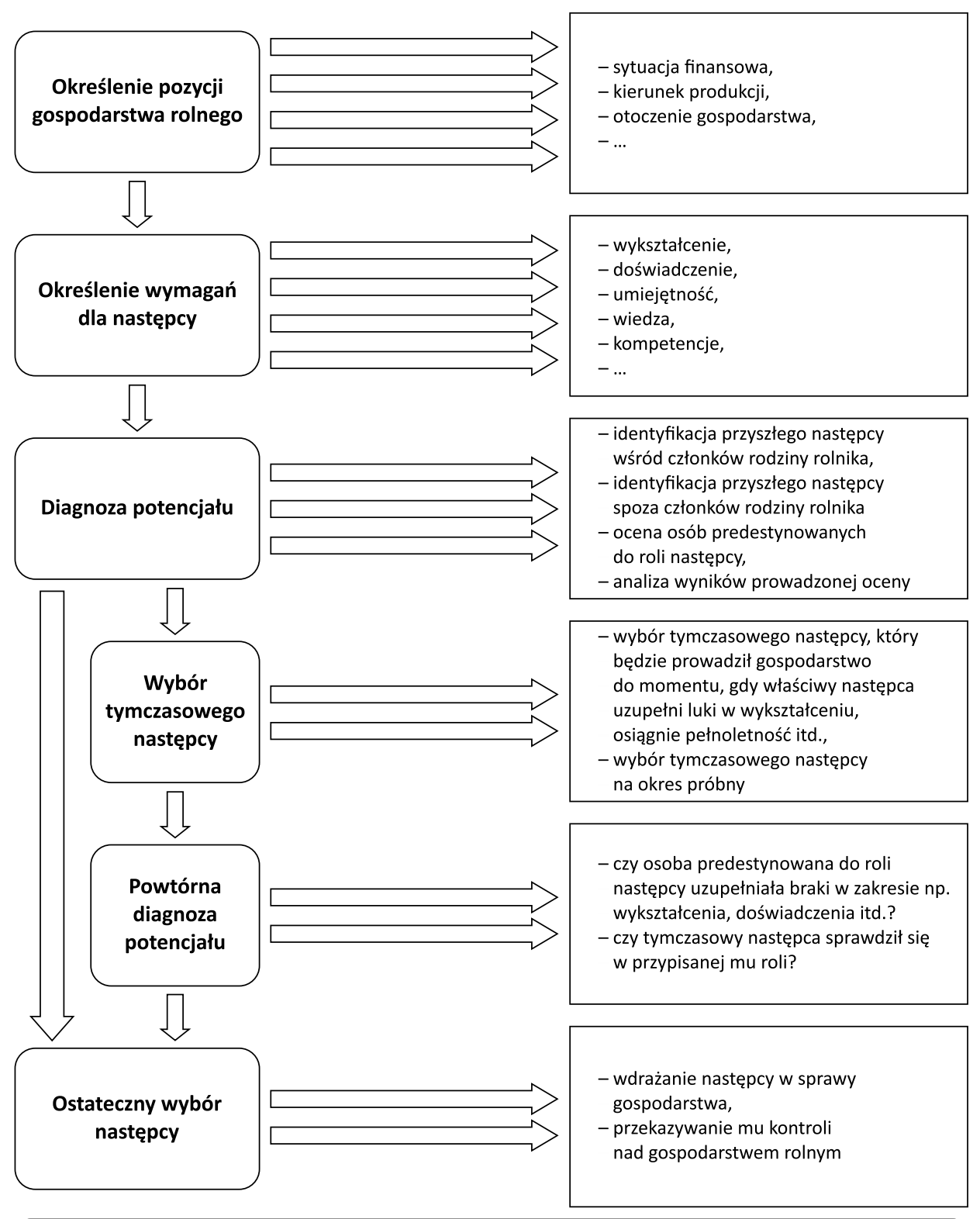

Aktywność dotychczasowych właścicieli po przejściu na emeryturę

Rysunek 3. Etapy planowania sukcesji w gospodarstwie rolnym

Figure 3. Elements of succession plan in family farms

Źródło: opracowanie własne.

Source: Own elaboration. 
obrazujące, jak planowanie sukcesji wygląda w gospodarstwach rolnych w wybranych krajach (Hwang, Choi 2014). W opracowaniu przyjęto założenie, że plan sukcesji będzie tworzony przez rolników, którzy przekażą gospodarstwo, stąd nie pojawia się w nim opcja zawieszenia działalności (sprzedaży gospodarstwa, jego wydzierżawienia itp.). Proces planowania sukcesji w gospodarstwie rolnym powinien rozpocząc się od określenia pozycji gospodarstwa. Podobnie jak w przypadku planowania sukcesji w firmach rodzinnych dotychczasowy kierownik winien wykazywać aktywną postawę $\mathrm{w}$ tym procesie i zrozumieć, że sama jego obecność nie warunkuje skuteczności całego postępowania. W momencie określania pozycji gospodarstwa ustala się, jakie obowiązki wykonuje kierownik gospodarstwa, jaką wiedzą i umiejętnościami dysponuje. Na tym etapie można także wskazać ewentualne braki, niedociągnięcia, które charakteryzują obecnego zarząazającego. Ustalenie pozycji gospodarstwa rolnego może prowadzić do wniosków, że zarządzaniem gospodarstwem rolnym zajmują się dwie osoby, np. rolnik i współmałżonka. Ta oczywista z pozoru konkluzja niesie ze sobą poważne konsekwencje - w planowaniu sukcesji należy uwzględnić nie jedną, ale dwie osoby jako potencjalnych sukcesorów. Określenie pozycji gospodarstwa rolnego uwzględnia także jego bieżącą sytuację finansową, a przede wszystkim wyniki produkcyjno-ekonomiczne. Sytuacja ta może mieć znaczenie przy kolejnym etapie procesu sukcesji, gdyż np. inne mogą być wymagania wobec przyszłego następcy, który ma przejąć gospodarstwo w świetnej kondycji finansowej, a inne wobec tego, który objąć ma gospodarstwo wymagające natychmiastowych inwestycji. Bardzo ważna jest analiza finansowa w zakresie przeszłej i obecnej kondycji finansowej gospodarstwa. Co więcej szczególna uwaga powinna być skupiona na przepływach pieniężnych w gospodarstwie, aby ustalić, jak będą wyglądały w najbliższym czasie, a w konsekwencji ocenić możliwości przetrwania gospodarstwa w kolejnych latach. Diagnoza pozycji gospodarstwa to także ustalenie, czy dochód przez nie generowany jest wystarczający, aby zaspokoić potrzeby obecnego i przyszłego pokolenia rolników. Koszty generowane w związku z utrzymaniem domu i rodziny są wysokie, a zmiany we własności gospodarstwa rolnego mogą wymagać $\mathrm{np}$. porzucenia pracy zarobkowej poza rolnictwem podejmowanej dotychczas przez sukcesora. Dochód stąd pozyskiwany może być ważnym składnikiem budżetu domowego rolnika i jego rodziny - czy gospodarstwo rolne będzie w stanie bez niego funkcjonować? Czy oprócz tego inne plany członków rodziny mogą wpłynąć na sytuację gospodarstwa - np. plany małżeńskie? Być może przyszły następca planuje rozpoczęcie budowy domu bądź chce uruchomić inne inwestycje będące znacznym obciążeniem dla budżetu rodziny rolnika. Czy występują inne uwarunkowania, które mogą w znaczący sposób wpłynąć na sytuację gospodarstwa? Pozycja gospodarstwa rolnego powinna zostać przedstawiona $\mathrm{z}$ uwzględnieniem 
otoczenia, czyli ujęciem czynników egzogenicznych, które mogą mieć wpływ na decyzje podejmowane w gospodarstwie. Wśród czynników tych mogą znaleźć się np.: polityka rolna, uwarunkowania i zapisy prawne, tradycja i wzorce postępowania czy sytuacja gospodarcza kraju. Określanie pozycji gospodarstwa rolnego wymaga zatem przede wszystkim zebrania i przeanalizowania informacji dotyczących sytuacji wewnętrznej gospodarstwa i wpływu na nią otoczenia.

Kolejny etap planu sukcesji to wskazanie wymagań względem następcy. Wymagania te powinny być określone na bazie obserwacji poczynionych w pierwszym etapie planowania, a dotyczyć mogą w szczególności: preferowanego poziomu wykształcenia następcy, jego wiedzy i doświadczeń praktycznych oraz umiejętności. Taka diagnoza oczekiwań wobec następcy pozwala - w sytuacji stwierdzenia braku osoby dysponującej pożądanymi cechami - na zapewnienie czasu niezbędnego dla rozwoju kompetencji sukcesorów.

Znajomość sytuacji gospodarstwa rolnego oraz wymagań względem sukcesora pozwala na pierwsze przymiarki w zakresie planowania osoby następcy. Może to być osoba $\mathrm{z}$ rodziny rolnika - należy tu nadmienić, że wielu rolników nie rozpatruje, czy wskazany przez nich na następcę członek rodziny będzie najlepszą alternatywą z punktu widzenia posiadanych przez niego kwalifikacji i doświadczeń (Succession... (b)) - może to być także osoba z rolnikiem niespokrewniona, gdy żaden z potomków rolnika nie chce objąć gospodarstwa bądź rolnik nie ma rodziny. Wskazanie potencjalnego następcy jest niewątpliwie jednym $\mathrm{z}$ najważniejszych punktów planu sukcesji, co więcej w literaturze można znaleźć przykłady planów, w których określenie sukcesora rozpoczyna proces przygotowania do sukcesji (Uchiyama 2014). Wreszcie może wystąpić sytuacja, że rolnik planuje na swoje miejsce osobę z rodziny, jednak w chwili gdy przekazuje on gospodarstwo, osoba ta nie jest jeszcze gotowa do jego objęcia. W tym momencie może wskazać na swoje miejsce następcę tymczasowego, który w kolejnych latach albo przekaże gospodarstwo krewnym rolnika, albo (za jego zgodą) dalej będzie je prowadzić. Rozwiązanie to wymagać będzie zapewne odrębnych regulacji prawnych i finansowych (np. kwestia wynagrodzenia dla tymczasowego następcy, który w przyszłości „odda gospodarstwo" rolne potomkowi rolnika), jednak na tym etapie są to jeszcze kwestie odległe, a samo planowanie ma przede wszystkim wcielić w życie takie działania, które umożliwią przetrwanie gospodarstwa. W sytuacji wybrania tymczasowego następcy kolejnym etapem będzie ponowna diagnoza potencjału. Jeżeli rozpoznanie sytuacji pozwoli na wyłonienie osoby, która spełni warunki stawiane przed sukcesorem, można dokonać wyboru ostatecznego następcy (nie oznacza to, że koniecznie musi to być osoba z rodziny rolnika).

Jako końcową fazę planowania sukcesji w gospodarstwie rolnym wskazano w opracowaniu określenie rodzaju aktywności podjętych przez dotychczasowego 
właściciela (właścicieli) po zaprzestaniu prowadzenia działalności. Jak już wcześniej wspomniano, moment „odsunięcia” kierownika gospodarstwa od jego dotychczasowych obowiązków może być szczególnie trudny i to zarówno dla niego, jak i dla sukcesora, dlatego warto już na etapie planowania nakreślić rodzaj aktywności seniorów po przejściu na emeryturę.

Finalną kwestią jest określenie, w jakim przedziale czasowym powinno się rozpocząć $w$ gospodarstwie opracowywanie planu sukcesji, a w konsekwencji, kiedy rolnik podejmie pierwsze rozmowy z następcą. Literatura wskazuje, że plan sukcesji $\mathrm{w}$ firmach rodzinnych powinien być opracowany minimum 5 lat przed przejściem na emeryturę. Okres 5-letni w przypadku gospodarstw rolnych jest jednak absolutnym minimum i postuluje się - bazując na informacjach dotyczących planowania sukcesji w gospodarstwach rolnych w innych krajach - aby planowanie rozpocząć już 10-15 lat przed momentem osiągnięcia wieku emerytalnego (Succession... (a); Farming Ahead 2013). Zwlekanie z decyzjami sukcesyjnymi może spowodować, że potomkowie rolnika znajdą zatrudnienie poza gospodarstwem rolnym i nie będą zainteresowani przejęciem schedy od nestorów.

\section{Wnioski}

Planowanie sukcesji - podobnie jak sukcesja - jest procesem, a nie zdarzeniem. Nie powinno być ono odkładane w czasie, gdyż producenci rolni - tak jak wszyscy inni przedsiębiorcy - nie są w stanie przewidzieć splotu okoliczności, które mogą mieć wpływ na ich gospodarstwa. Koncepcja przygotowywania planu sukcesji powinna być upowszechniana wśród rolników. Nawet jeżeli większość $\mathrm{z}$ nich nie opracuje pisemnej wersji takiego dokumentu, to na pewno zmusi ich to do postawienia pytań odnośnie do przyszłości gospodarstwa rolnego sobie i swoim najbliższym. Przegląd literatury i wyniki badań zagranicznych wykazują, że sukcesję planuje się zwykle w gospodarstwach rolnych z perspektywami rozwoju, generujących zadawalające dla rolników dochody, posiadających znaczną powierzchnię. W gospodarstwach rolnych działających w Polsce jest to zagadnienie mało bądź nawet $\mathrm{w}$ ogóle nieznane, natomiast badania $\mathrm{z}$ zakresu planowania sukcesji $\mathrm{w}$ gospodarstwach rolnych w Polsce nie były dotąd prowadzone.

Postuluje się, aby planowanie sukcesji było upowszechniane i nauczane wśród rolników. Na chwilę obecną brak jednak w tym względzie stosownych opracowań i wytycznych, np. ze strony Ministerstwa Rolnictwa i Rozwoju Wsi czy też innych instytucji zajmujących się problematyką rolnictwa. Wybrane podmioty komercyjne zajmują się tematyką sukcesji w firmach rodzinnych, jednak tylko nieliczne z nich oferują w tym momencie swoje usługi dla potrzeb rolników, a dodatkowo są to usługi odpłatne. 
Plan sukcesji może być zaczątkiem procesów sukcesyjnych w gospodarstwie rolnym, a idea jego opracowana ma służyć przede wszystkim rolnikowi, który na etapie konstrukcji planu może przemyśleć wiele spraw dotyczących przyszłości gospodarstwa. Wyznaczone w opracowaniu etapy planu sukcesji tworzą pewne ramy dla procesu następstwa i powinny być zweryfikowane na drodze badań empirycznych.

\section{Bibliografia}

Budzinowski R., Suchoń A. (2015). Relacja gospodarstwa rolnego i przedsiębiorstwa rolnego w świetle publicznych mechanizmów ich wspierania. W: P. Litwiniuk (red.). Prawne mechanizmy wspierania $i$ ochrony rolnictwa rodzinnego $w$ Polsce $i$ innych państwach Unii Europejskiej (s. 325-329). Warszawa: Fundacja Programów Pomocy dla Rolnictwa FAPA.

Dz.U. 2003 nr 64 poz. 592. Ustawa z dnia 11 kwietnia 2003 r. o kształtowaniu ustroju rolnego.

Dzięki nowym przepisom rodzinne gospodarstwa rolne mają być bardziej rentowne. www. farmer.pl. https://biznes.newseria.pl/news/dzieki_nowym_przepisom,p1977206614 [dostęp: styczeń-luty 2018].

Farming Ahead (2013). Intergenerational transfer of farms vital to agriculture's future. czerwiec 2013, 257. http://www.farmingahead.com.au/ [dostęp: styczeń-luty 2018].

Glauben T., Tietje H., Vogel S. (2004). The transfer of family businesses in Northern Germany and Austria. FE Working Papers, 0405, Department of Food Economics and Consumption Studies. Kiel: Christian-Albrechts-University of Kiel. http://www.food-econ.uni-kiel.de [dostęp: styczeń-luty 2018].

Gudorf T., Beckett D.I. (2009). Farm and ranch succession planning. Part I: The time is now. Journal of Practical Estate Planning, 11 (1), 51-58.

Henneberg M. (2016). Matka natura nie lubi myślących: Posłuszna małpa. Gazeta Wyborcza, 16-17.01.2016, 26-27.

Horak J., Surdej A. (2015). Firmy rodzinne zmieniają oblicze kapitalizmu. Magazyn Firm Rodzinnych „RELACJE”, 3 (11), 11-12.

Hwang J.-I., Choi Y.-J. (2014). Succession decisions in Korean family farms. Paper submitted to FFTC-RDA International Seminar on Enhanced Entry of Young Generation into Farming. 20-24 października, Jeonju, Korea. http://ap.fftc.agnet.org/ap_db.php?id=325 [dostęp: styczeń-luty 2018].

Inwood S.M., Sharp J.S. (2012). Farm persistence and adaptation at the rural-urban interface: Succession and farm adjustment. Journal of Rural Studies, 28, 107-117.

Johnsen S. (2004). The redefinition of family farming: Agricultural restructuring and farm adjustment in Waihemo, New Zealand. Journal of Rural Studies, 20, 419-432.

Kałuża H. (2009). Firmy rodzinne w XXI wieku. Specyfika i sukcesja. Zeszyty Naukowe SGGW w Warszawie. Ekonomika i Organizacja. Gospodarki Żywnościowej, 75, 49-61. 
Kerbler B. (2012). Factors affecting farm succession: The case of Slovenia. Agricultural Economics (AGRICECON), 58 (6), 285-298.

Klank L. (2006). Sukcesja gospodarstw rolnych w Polsce. Warszawa: Instytut Rozwoju Wsi i Rolnictwa PAN.

Kowalewska A. (red.) (2009). Firmy rodzinne w polskiej gospodarce: Szanse i wyzwania. Warszawa: Polska Agencja Rozwoju Przedsiębiorczości.

Lawton J. (2013). What are the Critical Success Factors for Succession Planning in Family Farms? A Systematic Review. Charlottetown: University of Prince Edward Island.

Lewandowska A. (red.) (2013). Diagnoza sytuacji sukcesyjnej w przedsiębiorstwach rodzin$n y c h w$ Polsce. Syntetyczny raport $z$ badań przeprowadzonych $w$ ramach projektu „Kody wartości - efektywna sukcesja w polskich firmach rodzinnych”. Poznań: Instytut Biznesu Rodzinnego. http://kodywartosci.pl/kw_raport.pdf [dostęp: styczeń-luty 2018].

Lewandowska A., Greser J., Jakubowski J. (2012). Sukcesja w firmie rodzinnej. W: M. Zawadka (red.). Firma $w$ rodzinie czy rodzina $w$ firmie. Metodologia wsparcia firm rodzinnych (s. 121-130). Warszawa: Polska Agencja Rozwoju Przedsiębiorczości. http://www. firmyrodzinne.eu/sites/default/files/attachments/sukcesja.pdf [dostęp: styczeń-luty 2018].

Mishra A.K., Johnson J.D., Morehart M.J. (2003). Retirement and succession planning of farm households: Results from a national survey. Paper for presentation at the National Public Policy Education Committee, Salt Lake City.

Musialska A. (2015). Ojcowizna. Czy młodzi będą chcieli zostać na gospodarstwie? agroFakt. pl, 1-6. https://www.agrofakt.pl/mlodzi-na-gospodarstwie/

Orzechowski K. (2011). Strategie rozwoju przedsiębiorstw rodzinnych w perspektywie sukcesji. W: A. Marjański (red.). Firmy rodzinne. Determinanty funkcjonowania i rozwoju zarządzanie rozwojem i zmianą. Przedsiębiorczość i Zarządzanie, 12 (7), 110-117.

Piekarski W., Rudzińska J. (2012). Znaczenie procesu sukcesji w polskich firmach rodzinnych. Logistyka, 4, 1200-1205.

Pijanowska J. (2016). Kiedy rolnik, kiedy przedsiębiorca? Wieś i Doradztwo, 2 (87), 15-20.

Rataj P. (2012). Czym jest plan sukcesji i jakie jest jego znaczenie w strategii rozwoju firmy? Magazyn Firm Rodzinnych „RELACJE”, 2, 4.

Safin K., Pluta J. (2014). Strategie sukcesyjne polskich przedsiębiorstw rodzinnych: Analiza wstępnych wyników badań. Przedsiębiorczość i Zarządzanie, 15 (7), Firmy Rodzinne: Współczesne nurty badań i praktyki zarządzania, 23-36.

Satoła Ł., Czekaj M. (2015). Czy płatności dla rolników przekazujących małe gospodarstwa będą sposobem na poprawę struktury agrarnej makroregionu Małopolska i Pogórze? Problemy Drobnych Gospodarstw Rolnych, 2, 57-67.

Spafford K. (2016). Ready or not. Ownership will transition to next generation. Delta Farm Press, 12 marca. http://deltafarmpress.com [dostęp: styczeń-luty 2018].

Succession planning: Face the future with confidence (a). http://www.farmingahead.com.au [dostęp: styczeń-luty 2018].

Succession planning for the transition of the family farm (b). http://www.bdo.ca [dostęp: styczeń-luty 2018].

Succession planning on the family farm (c). pnc.com/agriculture [dostęp: styczeń-luty 2018]. 
Sułkowski Ł. (2011). Definicje i typologie małych firm rodzinnych: Wnioski z badań. Przedsiębiorczość i Zarządzanie, 12 (6), 9-22.

Uchiyama T. (2014). Recent trends in young people's entry into farming in Japan: An international perspective. Paper submitted to FFTC-RDA International Seminar on Enhanced Entry of Young Generation into Farming, 20-24 października, Jeonju, Korea. http:// ap.fftc.agnet.org/ap_db.php?id=322\&print=1 [dostęp: styczeń-luty 2018].

Wheeler S., Bjornlund H., Zuo A., Edwards J. (2012). Handing down the farm? The increasing uncertainty of irrigated farm succession in Australia. Journal of Rural Studies, 28, 266-275.

Więcek-Janka E. (2014). Model sukcesji jako przykład zarządzania zmianą w przedsiębiorstwach rodzinnych. Marketing i Rynek, 5, 1249-1258.

Wilkinson J., Sykes L. (2007). A guide to succession: Sustaining families and farms. Canberra: Australian Government, Grains Research and Development Corporation. https://www. wool.com/globalassets/start/about-awi/publications/aguidetosuccession.pdf [dostęp: styczeń-luty 2018].

Wojewodzic T. (2013). Pozorna sukcesja: Zaburzenie cyklu życia gospodarstw rolniczych. Zeszyty Naukowe SGGW w Warszawie. Ekonomika i Organizacja Gospodarki Żywnościowej, 103, 141-152.

www.arimr.gov.pl [dostęp: styczeń-luty 2018].

www.omfara.gov.on.ca [dostęp: styczeń-luty 2018].

Ziętara W. (2009). Miary wielkości gospodarstw i przedsiębiorstw rolniczych. Roczniki Nauk Rolniczych, SERIA G, Ekonomika Rolnictwa, 96 (4), 267-276.

\title{
Succession Planning in Family Farms
}

\begin{abstract}
Succession is a very significant problem, and there are a lot of articles about succession in family business. In a family business, most successors come from the family. Succession is also very important in family farms. Continuous transfer of farm ownership among family members influences farms success in the future and it requires a development of a succession plan. The author was analyzing succession plans in family business and succession plans prepared for farms in developed countries of Europe and other parts of world. Based on this information a model succession plan for family farms was prepared. Succession planning should be promoted among farmers in Poland, as it stimulates thinking about the future of polish family farms. In Polish agriculture succession planning is not very popular, it is mostly unknown, and research in this field has not yet been conducted.
\end{abstract}

Keywords: planning, succession, family business, family farms. 